Research Article

\title{
CEO Media Exposure and Green Technological Innovation Decision: Evidence from Chinese Polluting Firms
}

\author{
Chen Wang, ${ }^{1}$ Yuanlin Hu, ${ }^{1}$ Jianhua Zhang $\mathbb{D}^{2}$, and Chenglin Miao ${ }^{3}$ \\ ${ }^{1}$ School of Business and Economics, Kunming University of Science and Technology, Kunming 650093, China \\ ${ }^{2}$ School of Economics and Management Northeast Petroleum University, Daqing 163318, China \\ ${ }^{3}$ School of Management Shandong Technology and Business University, Yantai 264003, China \\ Correspondence should be addressed to Jianhua Zhang; dqzhangjianhua@126.com
}

Received 9 June 2020; Revised 12 August 2020; Accepted 17 September 2020; Published 1 October 2020

Academic Editor: Yi Su

Copyright ( $\odot 2020$ Chen Wang et al. This is an open access article distributed under the Creative Commons Attribution License, which permits unrestricted use, distribution, and reproduction in any medium, provided the original work is properly cited.

The upper echelons theory is utilized to establish how CEO's attributes affect firm's technological innovation decisions. The extant literature has largely ignored the impacts of CEO media exposure. An unbalanced panel data analysis is used to examine the effects of CEO media exposure on Chinese polluting firm's green technological innovation. It is illustrated that CEO media exposure generally enhances Chinese polluting firms' green technological innovation decisions. In addition, we find that firms with state ownership and environmental regulations all moderate positively the relationship between CEO media exposure and green technological innovation. The research suggests that CEO media exposure appears to be a stimulus to firm's green technological innovation decisions.

\section{Introduction}

From an upper echelons perspective, chief executive officers' (CEOs) behaviors influence corporate policy and play an important role in driving firm's behaviors [1]. Prior studies have examined that corporate governance (i.e., board of directors and independent directors) or external normative values (i.e., institutional environment) affect green technological innovation decision [2-6]. Although some studies have investigated CEO media exposure impacts on firm's performance [7-9], few studies explore that CEO media exposure is another important factor on green innovation decision behavior. In fact, under the hierarchical organizational structure of modern enterprises, the investment decision-making behavior of enterprises is greatly influenced by CEO's will [10] and the firm's green technological innovation decision-making behavior is pronounced to a great extent by top management, especially CEO [11]. It is CEO who embeds his will into the enterprises that makes the enterprise show distinctive characteristics. To fill the gap in the literature, this study sheds light on how CEO media exposure affects green technological innovation decision.
By disclosing the relevant information and imposing public pressure on firm behaviors [8], CEO media exposure may influence firm's green technological innovation decisions. This is typically the case especially in Chinese firms, which are under unsound financial and legal environment and with more governmental interventions. In recent decades, China's environmental situation has been deteriorating because of its rapid economic growth [12]. Air pollution, water pollution, soil salinization, and man-made natural disasters do not only bring serious economic losses to China, but also aggravate social conflicts and endanger public health [13]. Will Chinese polluting enterprises consider green technological innovation while pursuing firm value? The relatively more complicated market environment in these economies also provides us with valuable opportunity to examine fully the relationship of CEO media coverage and the green technological innovation of the polluting firms. The exploration of the effects of the CEO media exposure on the firms' green technological innovation decisions will enrich the relevant literatures.

Besides, we also explore the previous researches by identifying the boundary conditions of institutional factors, 
such as the company's ownership structure and legal environments. We are curious to see if the significance and strength of impact between CEO media exposure and green technological innovation for Chinese firms are universally valid or subject to certain institutional environmental factors. Additionally, as for their special status in the Chinese economic system, state-owned enterprises (SOEs) attract much more attention. In February 2016, Information Office of the State Council held a press conference with Chinese and foreign media which were aimed at promoting air pollution control and the implementation of the Environmental Protection Law of the People's Republic of China. During the conference, some reporters expressed whether the special characteristic of SOEs hindered the enforcement of laws by the China Ministry of Environmental Protection, which led to the environmental control of SOEs lag behind that of non-SOEs. Thus, is it true that SOEs, which play a leading role in the national economic system, lag behind non-SOEs in fulfilling their environmental protection responsibilities because of government protection?

And considering the pressure of CEO media exposure on firm's green technological innovation, the current situation of environmental regulation in the formal system should not be ignored. At present, China is improving various legal systems gradually, and the external environment for enterprises to fulfill their environmental protection responsibilities is being established step by step. Particularly, the exposure of Chinese media increases the possibility for administrative agencies to intervene in illegal enterprises. Media supervision should be an effective supplement to the legal supervision system. The effect of environmental regulation is full of uncertainty. Its solution to environmental pollution problem is not exogenous and is restricted by other rules, laws, regulations, customs, and other systems. Therefore, it is meaningful to explore the role of environmental governance by combining the interaction between environmental regulation and CEO media exposure.

Our finding contributes in the following aspects. First, a thorough empirical investigation has been conducted by using 2597 firm-year observations; we find that CEO media exposure indeed has promoted firm's green technological innovation. Second, in order to identify the influence of specific institutional factors on the relationship of CEO media exposure and the firm's green technological innovation, we divide the full sample into subsamples according to a firms' ownership structure and the local legal environment of the firms. The subsample analysis allows us to examine the main research questions under different institutional conditions. Finally, our empirical findings provide more insight into the emerging Chinese polluting firms, which are closely related to economy and ecology. Such information is important for investors diversifying their portfolios and also for policy makers in China when regulating the balance between economic development and ecological protection. Findings from our empirical tests have the following implications. Considering long-term sustainable development of Chinese firms, well-known firms with more media exposure are expected to have more motivation and pressure for green technological innovation.
And this impact is largely strengthened for firms which are SOEs and with a better legal environment.

The remainder of the paper is organized as follows. We introduce the background and develop hypotheses in Section 2. The data and methodology are described in Section 3. Empirical results are presented in Section 4. And Section 5 concludes the paper.

\section{Literature Review and Hypothesis Development}

2.1. CEO Media Exposure and Green Technological Innovation Decision. CEO media exposure has an important impact on business activities, environmental governance, and corporate value $[8,14,15]$. CEO media exposure has a positive effect on firm's green technological innovation decision in the following ways.

First, CEO media exposure corrects managers' agency behavior and promotes green technological innovation by playing the role of external governor [16, 17]. China's corporate governance and legal framework are not perfect enough to provide good guiding principles for companies, while CEO media coverage is shown to be effective in monitoring CEOs' behaviors [7]. Within the enterprise, the characteristic of managers' concentration on short-term benefit makes them more tend to avoid risks than shareholders. Thus, they are more likely to invest in projects with low risk, quick results but low returns [18]. High risk and lagging return, which are the characteristics of green technological innovation, cause managers to worry about the investment and result in their unwillingness to promote green technological innovation. CEO media exposure can expose the problems of investment decision-making and improve the probability of being discovered by investors and regulatory authorities, thus arousing investors' high attention, and even the involvement of administrative and regulatory authorities, avoiding manager's investment decision deviation from the track of maximizing enterprise value [17]. The strong market pressure brought by media supervision compels executives to make rational decision on environmental protection innovation.

Second, CEO media exposure promotes enterprises' green technological innovation by diminishing harmful information asymmetries between enterprises and the outside, reducing the financial constraints of investment in green technological innovation. The media exposure is the intermediary which disseminates enterprise information to the public, reduces the information asymmetries between enterprises and stakeholders [19], and helps the public to collect and access enterprise information, hence improving information transparency [20]. Media may act as sort of governance control mechanism because media coverage plays the role of a watchdog to reduce information asymmetry between management and external constituents [21]. Information dissemination mechanism holds that, because information asymmetry, banks, and other financial institutions cannot grasp fully the true information of enterprises. However, media reporters can improve the information transparency to diminish information 
asymmetry between enterprise and stakeholders [22]. Through CEO media coverage, firms might become more credible, more familiar to investors, and thus more valuable [23]. This can help enterprises reduce the cost of debt financing and the difficulty of raising capital for innovative investments. The monitoring effect of media coverage is likely to reduce hidden news at the firm, forcing CEOs to take corrective action to reduce default risk [7]. Thus, media exposure has positive effect on promoting green technological innovation.

Third, CEO media also plays a significant part in social constructions, which affects the public how to evaluate the enterprises concerned and how their behavior meets the public's expectations [24]. In the context of increasingly transparent information disclosure and increasingly developed social media, companies with environmental accidents are more likely to receive media attention and then suffer from customer boycott, social condemnation, and government punishment, which seriously threaten the survival and development of enterprises [25]. A study indicates that CEOs who engage in social media are perceived to be more transparent and trustworthy [26]. According to legitimacy theory, legitimacy is a generalized perception or assumption that the actions of an entity are desirable, proper, or appropriate within some socially constructed system of norms, values, beliefs, and definitions [27]. The media's attention is not only the way for enterprises to obtain legitimacy, but also the source of crisis for enterprises' legitimacy [21]. With the attention of society to environmental issues, the investment of enterprises in green technological innovation has become an important aspect of the legitimacy of enterprises. In order to establish a good image, enterprises will carry out the legitimacy management of green technological innovation, so as to influence the public's understanding of environmental pollution and improve their level of environmental legitimacy.

Meanwhile, investors begin to focus on the environmental information of listed companies, especially when the enterprises carry out significant green technological innovation. It enhances not only the image and reputation of enterprises but also the capital market which will quickly respond positively to enterprises. Thus, with the enhancement of public awareness of environmental protection, CEO media exposure will force enterprises to consider the reputation effect of environmental protection innovation, which will further affect the profitability of enterprises. In this case, enterprises have the motivation to carry out green technological innovation.

Based on the above analysis, we propose the following hypothesis:

H1: CEO media exposure can enhance firm green technological innovation decision.

2.2. Moderating Effect of State Ownership. Ownership structure affects significantly corporate cognitive logic, leading to firms' heterogeneous responses via green technological innovation $[5,28]$. According to whether the ultimate controller is a government or other agency, Chinese enterprises are divided into SOEs and non-SOEs. There are great differences in responsibility burden, corporate governance, and market function between SOEs and non-SOEs in China [4]. Since the launch of the reform and the opening up policy in 1978, Chinese industrialization has simultaneously led to fast economic growth and increasing environmental pollution [28]. In the aspect of environmental governance, SOEs, as the pillar of national economy, play an essential role in the development of national economy. The public pays close attention to the image of these SOEs and has high expectations for their environmental responsibility performance. And the government's influence is critical environmental governance and environmental protection investment in China.

Moreover, reputation can stimulate and restrain the behavior of management. Media research has emphasized that positive press coverage can act as a valuable firm resource, in large part because it reduces the inherent uncertainty about firm and leader quality [29]. Therefore, the companies whose CEOs receive more positive media sentiment will have stronger firm performance [4]. One popular explanation for China's environmental problems is that political promotion mainly relies on GDP growth assessment and hence prompts local officials to engage in fierce competition over economic growth or the so-called political promotion tournament [30]. Fiscal decentralization provided sufficient incentives to local officials [31]. The good environmental reputation of enterprise improves the environmental performance of government.

Some research has shown that enterprises affiliated with higher levels of the government have initiated more innovation programs and received more public funding and policy support [32]. Thus, the goal and decision of enterprises' green technological innovation investment are also different. CEO will consciously arouse public praise through various actions and disseminate the correctness of enterprise decision-making to the society. With the enhancement of environmental control in various places, SOEs have shown more prominent performance in terms of environmental control constraints [33]. Due to the government's greater intervention and protection to SOEs [34], the cost of investment in green technological innovation will be guaranteed by the government's "umbrella." Under the premise of guaranteeing economic benefits, the managers of SOEs will not pay too much attention to environmental cost. In economic, social, and environmental benefits, more consideration should be given to environmental benefits and more green technological innovation should be made in enterprises. This can not only improve their reputation in the competitive market, but also meet their own political needs. However, private enterprises will pay more attention to the cost and benefit of environmental protection investment and their own interests [28]. Therefore, under the same production efficiency, CEOs have different awareness of environmental protection and make different decisions. It can be expected that SOEs have stronger motivation for environmental protection innovation than non-SOEs. 
Hence, we propose the following hypothesis:

$\mathrm{H} 2$ : state ownership positively moderates the relationship between CEO media exposure and green technological innovation.

\subsection{Moderating Effect of Environmental Regulations.} Legitimacy theory holds that an organization cannot succeed or even survive unless it believes in the goals, methods, and results recognized by society [27]. Environmental legitimacy refers to the public's overall recognition and evaluation of enterprises' environmental performance which is satisfactory and appropriate [35]. Environmental regulation is a rigid legitimacy requirement for enterprises, which plays a role in guiding enterprises' environmental behavior and is dominated by government administrative departments. It can reduce the probability of enterprises' illegal emission by improving the intensity of environmental pollution [6]. With the increase of intensity, the probability of punishment for illegal discharge will be increased, and the expected income of polluters will be reduced, forcing enterprises to increase investment in environmental facilities and technologies. In order to gain legitimacy recognition, enterprises can only increase investment in environmental protection innovation [36].

"Potter Hypothesis" holds that proper government management of the environment will stimulate enterprises to break the inherent mode of production and operation and product structure. Government's environmental supervision is the biggest source of pressure faced by enterprises when considering environmental problems. Enterprises will be forced to take certain measures to avoid punishment caused by noncompliance with environmental laws and regulations. On the one hand, enterprises should choose energy saving, emission reduction, and cleaner production; on the other hand, enterprises should accumulate business experiences through product innovation and process change and seek new and unique core competitiveness from them [37]. The goal of the government's environmental regulation policy is to limit the polluting production and operation of enterprises, so as to reduce pollution emissions and play a part in environmental protection. However, for the regulated target enterprises, environmental regulation will inevitably increase the cost of environmental compliance. To offset the "extra expenditure," enterprises usually choose environmental and technological innovation. The former solves the environmental pollution problem of enterprises from pollution sources and reduces the environmental cost of enterprises, while the latter expects to offset the environmental cost by improving the competitiveness of enterprises' products and their performance. The results show that the stricter environmental regulation is what the more capital enterprises will invest in cleaner production and technological innovation [2, 38, 39].

Thus, we propose the following hypothesis:

H3: environmental regulations positively moderate the relationship between $\mathrm{CEO}$ media exposure and green technological innovation.

\section{Methodology and Data}

3.1. Methodology. We use an unbalanced panel data regression analysis to analyze the effects of CEO media exposure on the green technological innovation decision. Our model is expressed as follows:

$$
\begin{aligned}
\text { Green_Inn }_{\mathrm{it}}= & \beta_{0}+\beta_{1} \text { CEO media }_{\mathrm{it}}+\sum_{k=2}^{10} \beta_{k} \mathrm{CV}_{\mathrm{it}} \\
& +\sum_{m=1}^{16} \varphi_{m} \text { Industry }_{i k t}+\sum_{n=1}^{10} \delta_{n} \text { Year }_{\text {nit }}+\varepsilon_{\mathrm{it}} .
\end{aligned}
$$

In previous studies, green technological innovation has been measured by indicators, such as green R\&D [40] ecolabelling in environmental product certification [26], and green patents [41]. Considering the availability of data in China, green patents were employed as the indicator of green technological innovation [42]. Because there are three types of patents, actual invention refers to new products or improvement from the proposed new technical solutions, and utility patent refers to the practical new technology solutions of the product's shape, structure, or their combination. Design appearance is a new design for a product's shape, pattern, or the combination of color and shape, which create a richer aesthetic experience. It seems that the technical content of actual invention is higher and the technical content of utility model and design appearance are relatively lower. Thus, the dependent variable, Green_Inn ${ }_{i t}$, is represented by two variables: green inventions, and green utility applications. First, we explicitly use green invention (Green Invention), which is the number of applications for green inventions. Second, we use green utility (Green Utility) to measure enterprise's applications for green utility patents. Our measure is more accurate than those used in the extant literature. Patents containing the keywords "green," "lowcarbon," "environmental," "energy-saving," "emissions reduction," "clean," “cycling," "saving," "sustainable," “ecology," "environmental pollution," and "environmental protection" are regarded as green patents [4, 43]. We have searched the applications for green patents and transformed the data in logarithm.

The independent variable CEO media ${ }_{i t}$ measures the extent of CEO media exposure. Following prior studies, CEO media is computed by using the natural log of one plus the number of CEOs news reports (i.e., $[7,8]$ ). Moreover, we included control variables $\left(\mathrm{CV}_{\mathrm{it}}\right)$ at four levels: characteristics of individual top manager, firm, industry, and year. First, we included some firm characteristics: firm size is measured as the natural logarithm of total assets at the end of the year. Leverage, a proxy for firm risk, is total liabilities over total assets. ROA (return on assets) is the net income over total assets. Cash holding is the ending balance of cash and cash equivalents over sales. R\&D is the natural logarithm of enterprise investment in research and development (R\&D), which affects patents. Subsidy is the natural logarithm of government green subsidies, which is the government subsidies for enterprises' green technological 
innovation. Top hold is the proportion of shares held by the largest shareholder. Second, TMT size is measured by the number of top management team (TMT) members. Duality equals 1 if the CEO also serves as chairman and 0 otherwise. Finally, dummies for the industry and year are included in the regressions.

Ten yearly dummies $(I=10)$ and 16 industry dummies $(K=16)$ are included in $(1) ; \beta_{0}$ is the intercept, $\varepsilon_{\mathrm{it}}$ is residuals, $\beta_{k}$ represents the regression coefficients of the control variables, and $\varphi_{m}$ and $\delta_{n}$ represent the regression coefficients of the industry and year dummy variables, respectively; $i$ represents the enterprises listed.
State ownership may moderate the relationship, which is important to see how effective they are in promoting innovations. And environmental regulations are targets set by the government with which firms must comply. Thus, we attempt to examine the impacts of state ownership and environmental regulations on innovations at the most highly polluting firms. Following Javorcik and Wei [44], environmental regulation (rule) variable is the number of environmental regulations issued by the national government. Variable definitions are shown in Table 1. To this end, we construct the following two regressions:

$$
\begin{aligned}
\text { Green_inn }_{\mathrm{it}}= & \beta_{0}+\beta_{1} \mathrm{CEO} \text { media }_{\mathrm{it}}+\beta_{2} \text { State }_{\mathrm{it}}+\beta_{3} \text { State }_{\mathrm{it}} * \text { CEO media } \\
& +\sum_{k=2}^{10} \beta_{k} \mathrm{CV}_{\mathrm{it}}+\sum_{m=1}^{16} \varphi_{m} \text { Industry }_{i k t}+\sum_{n=1}^{10} \delta_{n} \text { Year }_{\text {nit }}+\varepsilon_{\mathrm{it}} . \\
\text { Green_inn }_{\mathrm{it}}= & \beta_{0}+\beta_{1} \mathrm{CEO} \text { media }_{\mathrm{it}}+\beta_{2} \text { Rule }+\beta_{3} \text { Rule }_{\mathrm{it}} * \text { CEO media } \\
& +\sum_{\mathrm{it}}^{10} \beta_{k} \mathrm{CV}_{\mathrm{it}}+\sum_{m=1}^{16} \varphi_{m} \text { Industry }_{i k t}+\sum_{n=1}^{10} \delta_{n} \text { Year }_{\text {nit }}+\varepsilon_{\mathrm{it}} .
\end{aligned}
$$

3.2. Data and Sample. Our initial dataset includes all Chinese firms listed on Shanghai and Shenzhen Stock Exchanges over the period of 2010-2016. Zhang et al. [42] defined highly polluting industries as industries that discharge largescale industrial waste. We follow the definition of highly polluting industries used by the Guidelines on Environmental Information Disclosure of Listed Companies, published by the Ministry of Ecology and Environment of People's Republic of China in 2010.

Our final sample consists of 2,597 firm-year observations, covering 16 highly polluting industries at the twodigit SIC level: nonmetallic mineral products; power, thermal production and supply; metal products; petroleum processing, coking, and nuclear fuel processing; nonferrous metal smelting and calendaring processing; pharmaceutical manufacturing; chemical raw materials and chemical products manufacturing; rubber and plastic products; ferrous metal mining; chemical fiber manufacturing; gas production and supply; paper and paper products; coal mining and washing; ferrous metal smelting and rolling; nonferrous metals mine mining; ecological protection and environmental governance; and petroleum and natural gas mining.

Firms listed for less than one year are excluded. To minimize the impact of outliers, we follow common practice in the literature and winsorize all variables at the 1st and 99th percentiles (i.e., $[1,23])$. Our final sample consists of 2,597 firm-year observations.

The CEO media exposure information is extracted from Baidu, which is the leading online search engine in China. Following the method in Nguyen [23], we use the CEO's name and his firm's name to quantify CEO media exposure. We wrote a Python-based application to collect the number of news reports on CEOs from the Baidu news website (http://www.news.baidu.com).

Data on R\&D, government subsidies, age, the size of the TMT, duality, firm size, leverage, ownership, ROA, cash holdings, and others in highly polluting industries come from the China Stock Market and Accounting Research (CSMAR) database for the Chinese firms listed on the Shanghai and Shenzhen Stock Exchanges from 2010 to 2016. Prior studies have defined highly polluting industries as industries that discharge large-scale industrial waste [42]. We follow the definition of highly polluting industries used by the Ministry of Environmental Information Disclosure of Listed Companies in 2010.

We collected manually personal profiles of chairs and CEOs for each company. The data come primarily from the relevant securities financial websites (e.g., eastmoney.com, which is part of the stock exchanges' official website), the companies' annual reports for 2010-2016, and Baidu.com, Google, and related search engines. We also manually collected data on the ownership structure of each company from the CSMAR. The patent data on enterprises comes from the NIPA (National Intellectual Property Administration). The rule data come from the China Statistical Yearbook on the Environment.

We excluded "special treatment" companies (i.e., firms classified as failing by the stock exchanges) and companies listed on the exchange for less than two years.

\section{Analysis and Results}

4.1. Descriptive Statistics. Table 2 presents descriptive statistics for the characteristics of CEO media exposure and green technological innovation decision. The mean of CEO 
TABLE 1: Variable definitions.

\begin{tabular}{|c|c|}
\hline \multicolumn{2}{|c|}{ Dependent variables: green technological innovation decision } \\
\hline Green invention & The number of applications for environmental inventions \\
\hline Green utility & The number of applications for environmental utility patents \\
\hline \multicolumn{2}{|l|}{$\begin{array}{l}\text { Independent variables: CEO media } \\
\text { exposure }\end{array}$} \\
\hline CEO media & The natural $\log$ of one plus the number of CEOs news reports \\
\hline \multicolumn{2}{|l|}{ Moderating variables } \\
\hline State & $\begin{array}{c}\text { If the firm is an SOE, which is controlled by the government or its various entities, it equals } 1 \text { and } 0 \\
\text { otherwise }\end{array}$ \\
\hline Rule & The number of environmental regulations issued by the national government \\
\hline \multicolumn{2}{|l|}{ Control variables } \\
\hline Firm size & The natural logarithm of total assets at the end of the year \\
\hline Leverage & Total liabilities over total assets \\
\hline ROA & Net income over total assets \\
\hline Cash holding & The ending balance of cash and cash equivalents over sales \\
\hline $\mathrm{R} \& \mathrm{D}$ & $\begin{array}{c}\text { The natural logarithm of enterprise investment in research and development, which affects } \\
\text { patents }\end{array}$ \\
\hline Subsidy & The natural logarithm of government subsidies \\
\hline TMT & The number of top management team members \\
\hline Duality & Equals 1 if the CEO also serves as chairman and 0 otherwise \\
\hline
\end{tabular}

TABle 2: Characteristics of CEO media and green technological innovation.

\begin{tabular}{lcccccrrr}
\hline \multirow{2}{*}{ Year } & \multicolumn{2}{c}{ CEO media exposure } & \multicolumn{3}{c}{ Green invention } & \multicolumn{2}{c}{ Green utility } \\
& Mean & Std. dev. & Mean & Std. dev. & $\%$ & Mean & Std. dev. \\
\hline 2010 & 2.995 & 1.471 & 0.765 & 3.133 & 22.41 & 0.615 & 2.968 \\
2011 & 2.981 & 1.442 & 0.776 & 2.174 & 28.83 & 0.625 & 1.922 \\
2012 & 2.894 & 1.466 & 0.908 & 2.596 & 29.92 & 0.693 & 2.557 \\
2013 & 3.035 & 1.544 & 0.960 & 2.436 & 32.86 & 0.679 & 2.037 \\
2014 & 3.029 & 1.569 & 1.197 & 3.922 & 32.14 & 0.825 & 2.980 \\
2015 & 2.919 & 1.475 & 1.043 & 3.204 & 32.33 & 0.803 & 2.83 \\
2016 & 3.206 & 1.590 & 1.140 & 3.280 & 32.64 & 1.089 & 4.576 \\
$2010-2016$ & 3.008 & 1.510 & 0.970 & 3.015 & 30.15 & 0.761 & 22.92 \\
\hline
\end{tabular}

media exposure fluctuates between 2.995 in 2010 and 3.206 in 2016, which implies that the growth of CEO media exposure is not significant. The mean of environmental invention increases from 0.765 in 2010 to 1.140 in 2016, and the mean of environmental utility increases from 0.615 in 2010 to 1.089 in 2016, which signifies that the enterprises pay more and more attention to environmental protection.

Table 3 presents the summary statistics for the variables used in our analysis. Several points are worth noting here. First, the mean is 0.97 for green invention and 0.76 for green utility. And the standard deviation is 3.02 for environmental invention and 2.96 for environmental utility, indicating that there are great differences in green technological innovation among enterprises. Second, the mean value for media exposure is 3.01 and the 50th percentile is 2.77 , that is, less than $50 \%$ companies with the extent of CEO media exposure above average, which shows that CEO media exposure is not a universal phenomenon. Third, $25 \%$ of state is 1 , showing that $25 \%$ of the sample companies are SOEs. R\&D shows the investment in research and development. The 10th percentile is 15.66 and the mean is 17.48 , which indicate that the investment in $\mathrm{R} \& \mathrm{D}$ of most sample companies is above average.
Table 4 presents descriptive correlations for all the variables. To ensure no strong bivariate correlation between these variables, we computed the variance inflation factor (VIF). The VIF is below 10 for all regression models, the cut-off point. The result indicates that no serious multicollinearity issues are present in our regression analyses. As expected, CEO media exposure is significantly related to the green technological innovation variables (green invention and green utility), a result consistent with H1.

4.2. Preliminary Results. Table 5 provides a univariate analysis of green invention and green utility for firms with different levels of CEO media exposure and environmental regulations. And we also divide the sample into SOEs and non-SOEs. Among sample firms, firms with high level CEO exposure have a higher number of green inventions than low level peers ( 0.431 vs. $0.35 ; p<0.05$ for the difference); firms with high level rule have more green inventions than firms with low level ( 0.666 vs. $0.338 ; p<0.01)$; non-SOEs have fewer green inventions than SOEs (0.587 vs. 0.283 ; $p<0.01)$. The results of green utility models are similar to 
TABLe 3: Descriptive statistics per firm.

\begin{tabular}{|c|c|c|c|c|c|c|c|c|c|}
\hline Variable & Mean & Std. dev. & Min & P10 & p25 & p50 & p75 & P90 & $\operatorname{Max}$ \\
\hline Green invention & 0.97 & 3.02 & 0 & 0 & 0 & 0 & 1 & 3 & 59 \\
\hline Green utility & 0.76 & 2.96 & 0 & 0 & 0 & 0 & 0 & 2 & 55 \\
\hline Media exposure & 3.01 & 1.51 & 0 & 1.10 & 1.95 & 2.77 & 4.29 & 4.98 & 7.21 \\
\hline State & 0.37 & 0.48 & 0 & 0 & 0 & 0 & 1 & 1 & 1 \\
\hline Rule & 1.40 & 0.70 & 0 & 0 & 0.69 & 1.79 & 1.79 & 2.08 & 2.20 \\
\hline Firm size & 22.17 & 1.22 & 19.06 & 20.82 & 21.31 & 21.95 & 22.88 & 23.9 & 26.43 \\
\hline Leverage & 0.44 & 0.22 & 0.04 & 0.14 & 0.25 & 0.43 & 0.61 & 0.73 & 1.21 \\
\hline ROA & 0.04 & 0.06 & -0.26 & 0 & 0.01 & 0.04 & 0.07 & 0.1 & 0.23 \\
\hline Cash holding & 0.31 & 0.40 & 0.01 & 0.05 & 0.09 & 0.17 & 0.36 & 0.73 & 2.67 \\
\hline $\mathrm{R} \& \mathrm{D}$ & 17.48 & 1.54 & 0 & 15.66 & 16.65 & 17.58 & 18.37 & 19.3 & 22.08 \\
\hline Subsidy & 16.27 & 1.85 & 0 & 14.4 & 15.4 & 16.3 & 17.31 & 18.25 & 21.79 \\
\hline Top hold & 0.36 & 0.15 & 0.04 & 0.18 & 0.24 & 0.34 & 0.47 & 0.56 & 0.89 \\
\hline TMT size & 7.37 & 2.40 & 3 & 5 & 6 & 7 & 9 & 10 & 15 \\
\hline CEO duality & 0.23 & 0.42 & 0 & 0 & 0 & 0 & 0 & 1 & 1 \\
\hline
\end{tabular}

those of green invention, which are consistent with our hypothesis.

4.3. Regression Analysis and Results. We have examined the effect of CEO media exposure on green technological innovation (green invention and green utility). As we know, the dependent variable is counted data with zero entries, and the typical approach is to use the negative binomial (NB) model. The distribution of green invention (mean value $=0.97$ and $s d=3.02$ ) and green utility counts (mean value $=0.76$ and $s d=2.96$ ) shows a large dispersion in Table 3 with large standard deviation as compared to the mean [45]. NB model might not be able to handle the presence of excess zero counts in green technological innovation data. Thus, following Fung et al. [46], we adopt the zero-inflated negative binomial (ZINB) method for our analysis by Stata 15.0 and choosing option vce (robust) which produces robust standard error estimates for our linear panel models.

Table 6 presents ZINB regression results of CEO media exposure on green innovation variables in different institutional situations using (1)-(3). In models 1 and 4 for the full sample, the coefficient of CEO media is significantly and positively correlated with green invention and green utility $(p<0.01)$, suggesting that firms with high level CEO exposure are able to increase firms green innovation ability, supporting $\mathrm{H} 1$.

Model 2 and model 5 show, respectively, the interaction effect of CEO media exposure and state on green invention and green utility, with the inclusion of the dummy variables industry and year as control variables. CEO media exposure has a positive and significant coefficient $(\beta=0.165, p<0.01)$; state does not have a significant coefficient $(\beta=-0.271$, $p>0.1$ ). The coefficient of the interaction of CEO media exposure and state is also positive and significant $(\beta=0.128$, $p<0.01$ ). An average marginal effect (AME) of state on green invention is 0.212 . Model 5 examines the interaction effect of CEO media exposure and state on green utility. CEO media exposure also has a positive and significant coefficient $(\beta=0.203, p<0.01)$, the coefficient of CEO media $\times$ state on green utility is also positive and significant $(\beta=0.267, p<0.1)$, and an average marginal effect (AME) of state on green utility is 0.302 , which indicates that state enhances the positive effect of CEO media exposure on green innovation; $\mathrm{H} 2$ is thus supported.

Model 3 tests the moderating effect of environmental regulations on the relationship between CEO media exposure and green invention. The effect of CEO media exposure on green invention is insignificant $(\beta=0.094, p>0.1)$; the effect of rule is negative and significant $(\beta=-1.406, p<0.01)$. The moderating effect of the interaction term is positive and significant $(\beta=0.085, p<0.05)$. An average marginal effect (AME) of rule on green invention is 0.213 . The results indicate that environmental regulation can increase the investment in environmental innovation. Similarly, model 6 presents the moderating effect of environmental regulation on the relationship between CEO media exposure and green utility. The effect of CEO media exposure on green utility is positive and significant $(\beta=0.159, p<0.1)$; the effect of rule is negative and insignificant $(\beta=-0.433, p>0.1)$; and the effect of the interaction term CEO media $\times$ rule is also positive and significant $(\beta=0.098, p<0.05)$; an average marginal effect (AME) of rule on green utility is 0.296 , implying results similar to those for model 3. The results of models 3 and model 4 clearly show that the effect of CEO media on green innovation is more pronounced at firms with high environmental regulation than that at firms with low environmental regulation, further supporting $\mathrm{H} 3$.

4.4. Robustness Check. First, the positive relation between CEO media exposure and green technological innovation may be driven by the current patents of the firm. Consequently, the direction of causality may run from green technological innovation to CEO media exposure. To address this potential endogeneity, we modify our CEO media exposure by using dependent variable forward two periods. This has the effect of ensuring that the measure of CEO media exposure is unrelated to the period in which green invention or green utility is released or measured.

Table 7 reports parameters estimates after controlling for endogeneity. These results largely are consistent with results reported in Table 6. The coefficient of CEO media is positive and significant. The coefficients of $\mathrm{CEO}$ media $\times$ state and $\mathrm{CEO}$ media $\times$ rule are only significant on green utility, 


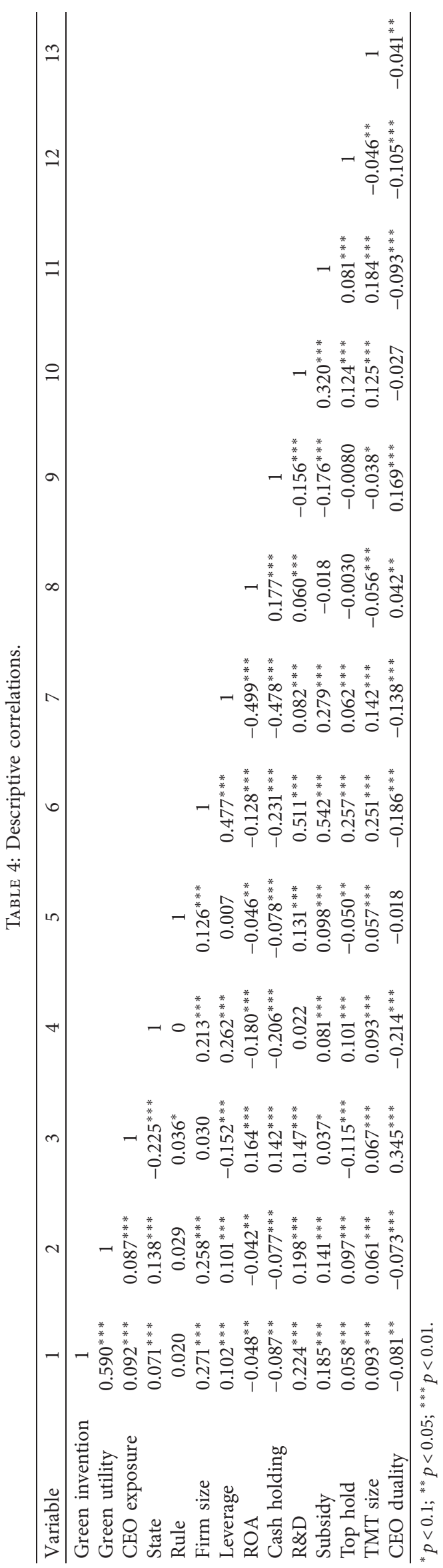


TABLE 5: The univariate analysis of green invention and green utility.

\begin{tabular}{|c|c|c|c|c|c|c|}
\hline Type & Level & $\begin{array}{c}\text { Number of } \\
\text { observations }\end{array}$ & $\begin{array}{c}\text { Green } \\
\text { invention }\end{array}$ & $\begin{array}{l}\text { Green } \\
\text { utility }\end{array}$ & $\begin{array}{l}t \text {-test for green } \\
\text { invention }\end{array}$ & $t$-test for green utility \\
\hline CEO media & High & 1554 & 0.431 & 0.308 & \multirow{2}{*}{$0.081^{* *}$} & \multirow{2}{*}{$0.068^{* * *}$} \\
\hline exposure & Low & 1421 & 0.35 & 0.239 & & \\
\hline State & $\begin{array}{c}\text { With } \\
\text { Without }\end{array}$ & $\begin{array}{l}1067 \\
1908\end{array}$ & $\begin{array}{l}0.587 \\
0.283\end{array}$ & $\begin{array}{c}0.391 \\
0.21\end{array}$ & $0.304^{* * *}$ & $0.181^{* * *}$ \\
\hline Rule & $\begin{array}{l}\text { High } \\
\text { Low }\end{array}$ & $\begin{array}{c}490 \\
2485\end{array}$ & $\begin{array}{l}0.666 \\
0.338\end{array}$ & $\begin{array}{l}0.418 \\
0.247\end{array}$ & $0.328^{* * *}$ & $0.171^{* * *}$ \\
\hline
\end{tabular}

${ }^{*} p<0.1 ;{ }^{* *} p<0.05 ;{ }^{* * *} p<0.01$.

TABLE 6: Zero-inflated negative binomial regression of CEO media exposure on green invention and green utility.

\begin{tabular}{|c|c|c|c|c|c|c|}
\hline \multirow{2}{*}{ Variables } & \multicolumn{3}{|c|}{ Green invention $_{t}$} & \multicolumn{3}{|c|}{ Green utility $_{\mathrm{t}}$} \\
\hline & (1) & $(2)$ & (3) & (4) & (5) & (6) \\
\hline CEO media & $\begin{array}{c}0.222^{* * *} \\
(0.033)\end{array}$ & $\begin{array}{c}0.165^{* * *} \\
(0.044)\end{array}$ & $\begin{array}{c}0.094 \\
(0.070)\end{array}$ & $\begin{array}{c}0.309^{* * *} \\
(0.043)\end{array}$ & $\begin{array}{c}0.203^{* * *} \\
(0.056)\end{array}$ & $\begin{array}{l}0.159^{*} \\
(0.096)\end{array}$ \\
\hline State & & $\begin{array}{c}-0.271 \\
(0.209)\end{array}$ & & & $\begin{array}{c}0.139 \\
(0.269)\end{array}$ & \\
\hline CEO media $\times$ state & & $\begin{array}{l}0.128^{* *} \\
(0.063)\end{array}$ & & & $\begin{array}{c}0.267^{* * *} \\
(0.078)\end{array}$ & \\
\hline Rule & & & $\begin{array}{c}-1.406^{* * *} \\
(0.386)\end{array}$ & & & $\begin{array}{l}-0.433 \\
(0.279)\end{array}$ \\
\hline CEO media $\times$ rule & & & $\begin{array}{c}0.085^{* *} \\
(0.042)\end{array}$ & & & $\begin{array}{l}0.098^{*} \\
(0.057)\end{array}$ \\
\hline Firm size & $\begin{array}{c}-0.263^{* * *} \\
(0.042)\end{array}$ & $\begin{array}{c}-0.263^{* * *} \\
(0.043)\end{array}$ & $\begin{array}{c}-0.222^{* * *} \\
(0.044)\end{array}$ & $\begin{array}{c}-0.260^{* * *} \\
(0.047)\end{array}$ & $\begin{array}{c}-0.282^{* * *} \\
(0.048)\end{array}$ & $\begin{array}{c}-0.238^{* * *} \\
(0.048)\end{array}$ \\
\hline Leverage & $\begin{array}{c}0.328 \\
(0.309)\end{array}$ & $\begin{array}{c}0.379 \\
(0.308)\end{array}$ & $\begin{array}{c}0.264 \\
(0.308)\end{array}$ & $\begin{array}{c}0.955^{* *} \\
(0.421)\end{array}$ & $\begin{array}{l}0.792^{*} \\
(0.410)\end{array}$ & $\begin{array}{l}0.871^{* *} \\
(0.424)\end{array}$ \\
\hline ROA & $\begin{array}{l}-0.513 \\
(1.099)\end{array}$ & $\begin{array}{l}-0.237 \\
(1.108)\end{array}$ & $\begin{array}{l}-0.538 \\
(1.091)\end{array}$ & $\begin{array}{c}0.575 \\
(1.482)\end{array}$ & $\begin{array}{c}0.468 \\
(1.481)\end{array}$ & $\begin{array}{c}0.379 \\
(1.487)\end{array}$ \\
\hline Cash holding & $\begin{array}{c}-0.423^{* * *} \\
(0.162)\end{array}$ & $\begin{array}{c}-0.362^{* *} \\
(0.164)\end{array}$ & $\begin{array}{c}-0.348^{* *} \\
(0.162)\end{array}$ & $\begin{array}{c}-0.371^{* *} \\
(0.189)\end{array}$ & $\begin{array}{l}-0.049 \\
(0.189)\end{array}$ & $\begin{array}{c}-0.342^{*} \\
(0.190)\end{array}$ \\
\hline $\mathrm{R} \& \mathrm{D}$ & $\begin{array}{c}0.227^{* * *} \\
(0.039)\end{array}$ & $\begin{array}{c}0.230^{* * *} \\
(0.039)\end{array}$ & $\begin{array}{c}0.232^{* * * *} \\
(0.039)\end{array}$ & $\begin{array}{c}0.203^{* * *} \\
(0.047)\end{array}$ & $\begin{array}{c}0.196^{* * *} \\
(0.046)\end{array}$ & $\begin{array}{c}0.205^{* * *} \\
(0.047)\end{array}$ \\
\hline Subsidy & $\begin{array}{c}0.121^{* * *} \\
(0.031)\end{array}$ & $\begin{array}{c}0.121^{* * *} \\
(0.031)\end{array}$ & $\begin{array}{c}0.124^{* * *} \\
(0.031)\end{array}$ & $\begin{array}{l}0.065^{* *} \\
(0.031)\end{array}$ & $\begin{array}{c}0.084^{* * *} \\
(0.032)\end{array}$ & $\begin{array}{c}0.065^{* *} \\
(0.031)\end{array}$ \\
\hline Top hold & $\begin{array}{l}-0.227 \\
(0.335)\end{array}$ & $\begin{array}{l}-0.273 \\
(0.337)\end{array}$ & $\begin{array}{l}-0.167 \\
(0.335)\end{array}$ & $\begin{array}{l}-0.120 \\
(0.439)\end{array}$ & $\begin{array}{c}0.008 \\
(0.430)\end{array}$ & $\begin{array}{l}-0.133 \\
(0.441)\end{array}$ \\
\hline TMT size & $\begin{array}{c}0.073^{* * *} \\
(0.020)\end{array}$ & $\begin{array}{c}0.070^{* * * *} \\
(0.020)\end{array}$ & $\begin{array}{c}0.074^{* * * *} \\
(0.020)\end{array}$ & $\begin{array}{c}0.073^{* * *} \\
(0.025)\end{array}$ & $\begin{array}{c}0.067^{* * *} \\
(0.024)\end{array}$ & $\begin{array}{c}0.075^{* * *} \\
(0.025)\end{array}$ \\
\hline Duality & $\begin{array}{c}-0.601^{* * *} \\
(0.121)\end{array}$ & $\begin{array}{c}-0.547^{* * *} \\
(0.123)\end{array}$ & $\begin{array}{c}-0.578^{* * *} \\
(0.121)\end{array}$ & $\begin{array}{c}-0.542^{* * *} \\
(0.161)\end{array}$ & $\begin{array}{c}-0.403^{* *} \\
(0.158)\end{array}$ & $\begin{array}{c}-0.519^{* * * *} \\
(0.161)\end{array}$ \\
\hline Constant & $\begin{array}{c}1.095^{* * *} \\
(0.239)\end{array}$ & $\begin{array}{c}1.135^{* * *} \\
(0.250)\end{array}$ & $\begin{array}{c}1.095^{* * *} \\
(0.247)\end{array}$ & $\begin{array}{c}1.729^{* * *} \\
(0.066)\end{array}$ & $\begin{array}{c}1.632^{* * *} \\
(0.068)\end{array}$ & $\begin{array}{c}1.723^{* * *} \\
(0.066)\end{array}$ \\
\hline Year & Yes & Yes & Yes & Yes & Yes & Yes \\
\hline Industry & Yes & Yes & Yes & Yes & Yes & Yes \\
\hline $\mathrm{N}$ & 2597 & 2597 & 2597 & 2597 & 2597 & 2597 \\
\hline $\mathrm{Chi}^{2}$ & 366.274 & 366.062 & 379.864 & 332.946 & 391.544 & 337.586 \\
\hline
\end{tabular}

Note that standard errors are in parentheses: ${ }^{*} p<0.1 ;{ }^{* *} p<0.05 ;{ }^{* * *} p<0.01$.

indicating that the moderating effect of state ownership and environmental regulation mainly acts on green utility. These results support our hypotheses.

Second, in an attempt to strictly control for observed selection bias, a propensity score matching (PSM) identification strategy is conducted. In the first stage of this estimation strategy, if firms with high level CEO media exposure are fundamentally different from those with low level, then the control variables employed in the main specification that capture linear relations may be inadequate. To alleviate concerns over such functional form misspecification biases, we use the methodology of https:// onlinelibrary.wiley.com/doi/full/10.1111/j.1540-6288.2011. 00305.x [47]; we implement a commonly used matching algorithm: nearest neighbor matching. And we create two data samples that are comparable across all the control variables but differ only on the level of media exposure. For the PSM analysis, we match a firm with low CEO media exposure to the firm with high CEO media exposure using the closest propensity score estimated from the first stage. 
TABLE 7: Dependent variable forward two periods.

\begin{tabular}{|c|c|c|c|c|c|c|}
\hline \multirow{2}{*}{ Variables } & \multicolumn{3}{|c|}{ Green invention $_{t+2}$} & \multicolumn{3}{|c|}{ Green utility $y_{t+2}$} \\
\hline & $(1)$ & $(2)$ & (3) & $(4)$ & $(5)$ & $(6)$ \\
\hline CEO media & $\begin{array}{c}0.223^{* * *} \\
(0.036)\end{array}$ & $\begin{array}{c}0.185^{* * *} \\
(0.049)\end{array}$ & $\begin{array}{c}0.133^{* *} \\
(0.064)\end{array}$ & $\begin{array}{c}0.327^{* * *} \\
(0.053)\end{array}$ & $\begin{array}{l}0.151^{* *} \\
(0.068)\end{array}$ & $\begin{array}{c}0.180^{* *} \\
(0.089)\end{array}$ \\
\hline State & & $\begin{array}{l}-0.105 \\
(0.233)\end{array}$ & & & $\begin{array}{l}-0.215 \\
(0.317)\end{array}$ & \\
\hline CEO media $\times$ state & & $\begin{array}{c}0.084 \\
(0.070)\end{array}$ & & & $\begin{array}{c}0.376^{* * *} \\
(0.093)\end{array}$ & \\
\hline Rule & & & $\begin{array}{c}-1.136^{* * *} \\
(0.404)\end{array}$ & & & $\begin{array}{c}-0.931^{* *} \\
(0.396)\end{array}$ \\
\hline CEO media $\times$ rule & & & $\begin{array}{c}0.071 \\
(0.044)\end{array}$ & & & $\begin{array}{l}0.117^{* *} \\
(0.059)\end{array}$ \\
\hline Firm size & $\begin{array}{c}-0.198^{* * *} \\
(0.045)\end{array}$ & $\begin{array}{c}-0.205^{* * *} \\
(0.046)\end{array}$ & $\begin{array}{c}-0.163^{* * *} \\
(0.047)\end{array}$ & $\begin{array}{c}-0.224^{* * *} \\
(0.056)\end{array}$ & $\begin{array}{c}-0.223^{* * *} \\
(0.056)\end{array}$ & $\begin{array}{c}-0.200^{* * *} \\
(0.057)\end{array}$ \\
\hline Leverage & $\begin{array}{c}0.499 \\
(0.367)\end{array}$ & $\begin{array}{c}0.529 \\
(0.366)\end{array}$ & $\begin{array}{c}0.461 \\
(0.366)\end{array}$ & $\begin{array}{l}0.887^{*} \\
(0.512)\end{array}$ & $\begin{array}{c}0.658 \\
(0.495)\end{array}$ & $\begin{array}{c}0.788 \\
(0.515)\end{array}$ \\
\hline ROA & $\begin{array}{l}-1.201 \\
(1.269)\end{array}$ & $\begin{array}{r}-0.980 \\
(1.278)\end{array}$ & $\begin{array}{r}-0.986 \\
(1.266)\end{array}$ & $\begin{array}{c}1.448 \\
(1.693)\end{array}$ & $\begin{array}{c}0.622 \\
(1.712)\end{array}$ & $\begin{array}{c}1.526 \\
(1.689)\end{array}$ \\
\hline Cash holding & $\begin{array}{l}-0.117 \\
(0.164)\end{array}$ & $\begin{array}{l}-0.046 \\
(0.169)\end{array}$ & $\begin{array}{c}-0.092 \\
(0.163)\end{array}$ & $\begin{array}{c}-0.282 \\
(0.235)\end{array}$ & $\begin{array}{c}0.103 \\
(0.231)\end{array}$ & $\begin{array}{l}-0.238 \\
(0.236)\end{array}$ \\
\hline $\mathrm{R} \& \mathrm{D}$ & $\begin{array}{c}0.193^{* * *} \\
(0.045)\end{array}$ & $\begin{array}{c}0.199^{* * *} \\
(0.045)\end{array}$ & $\begin{array}{c}0.190^{* * *} \\
(0.045)\end{array}$ & $\begin{array}{c}0.172^{* * *} \\
(0.055)\end{array}$ & $\begin{array}{c}0.171^{* * *} \\
(0.054)\end{array}$ & $\begin{array}{c}0.181^{* * *} \\
(0.055)\end{array}$ \\
\hline Subsidy & $\begin{array}{c}0.086^{* * *} \\
(0.031)\end{array}$ & $\begin{array}{c}0.088^{* * *} \\
(0.031)\end{array}$ & $\begin{array}{c}0.086^{* * *} \\
(0.031)\end{array}$ & $\begin{array}{c}0.049 \\
(0.035)\end{array}$ & $\begin{array}{l}0.064^{*} \\
(0.036)\end{array}$ & $\begin{array}{c}0.049 \\
(0.036)\end{array}$ \\
\hline Top hold & $\begin{array}{c}-0.537 \\
(0.387)\end{array}$ & $\begin{array}{l}-0.541 \\
(0.387)\end{array}$ & $\begin{array}{r}-0.476 \\
(0.385)\end{array}$ & $\begin{array}{c}-0.352 \\
(0.503)\end{array}$ & $\begin{array}{c}-0.244 \\
(0.491)\end{array}$ & $\begin{array}{l}-0.370 \\
(0.505)\end{array}$ \\
\hline TMT size & $\begin{array}{c}0.032 \\
(0.024)\end{array}$ & $\begin{array}{c}0.031 \\
(0.024)\end{array}$ & $\begin{array}{c}0.035 \\
(0.024)\end{array}$ & $\begin{array}{c}0.114^{* * *} \\
(0.031)\end{array}$ & $\begin{array}{c}0.073^{* *} \\
(0.030)\end{array}$ & $\begin{array}{c}0.120^{* * *} \\
(0.031)\end{array}$ \\
\hline Duality & $\begin{array}{c}-0.637^{* * *} \\
(0.138)\end{array}$ & $\begin{array}{c}-0.592^{* * *} \\
(0.141)\end{array}$ & $\begin{array}{c}-0.612^{* * *} \\
(0.138)\end{array}$ & $\begin{array}{c}-0.781^{* * *} \\
(0.192)\end{array}$ & $\begin{array}{c}-0.639^{* * *} \\
(0.186)\end{array}$ & $\begin{array}{c}-0.789^{* * *} \\
(0.192)\end{array}$ \\
\hline Constant & $\begin{array}{c}1.135^{* * *} \\
(0.280)\end{array}$ & $\begin{array}{c}1.161^{* * *} \\
(0.301)\end{array}$ & $\begin{array}{c}1.143^{* * *} \\
(0.292)\end{array}$ & $\begin{array}{c}1.767^{* * *} \\
(0.074)\end{array}$ & $\begin{array}{c}1.650^{* * *} \\
(0.082)\end{array}$ & $\begin{array}{c}1.758^{* * *} \\
(0.073)\end{array}$ \\
\hline Year & Yes & Yes & Yes & Yes & Yes & Yes \\
\hline Industry & Yes & Yes & Yes & Yes & Yes & Yes \\
\hline $\mathrm{N}$ & 1855 & 1855 & 1855 & 1855 & 1855 & 1855 \\
\hline $\mathrm{Chi}^{2}$ & 243.554 & 243.661 & 252.839 & 212.109 & 257.527 & 227.563 \\
\hline
\end{tabular}

Note that standard errors are in parentheses: ${ }^{*} p<0.1 ;{ }^{* *} p<0.05 ;{ }^{* * *} p<0.01$.

TABLE 8: Comparison of differences before and after variable matching.

\begin{tabular}{|c|c|c|c|c|c|}
\hline \multirow{2}{*}{ Variable } & \multirow{2}{*}{$\begin{array}{l}\text { Unmatched } \\
\text { Matched }\end{array}$} & \multicolumn{2}{|c|}{ Mean } & \multicolumn{2}{|c|}{$t$-test } \\
\hline & & Treated & Control & $\mathrm{T}$ & $p>t$ \\
\hline \multirow{2}{*}{ Firm size } & $\mathrm{U}$ & 22.153 & 22.166 & -0.280 & 0.782 \\
\hline & $\mathrm{M}$ & 22.153 & 22.102 & 1.040 & 0.300 \\
\hline \multirow{2}{*}{ Leverage } & $\mathrm{U}$ & 0.402 & 0.466 & -7.480 & 0.000 \\
\hline & M & 0.402 & 0.402 & -0.010 & 0.991 \\
\hline \multirow{2}{*}{ ROA } & $\mathrm{U}$ & 0.049 & 0.032 & 7.720 & 0.000 \\
\hline & $\mathrm{M}$ & 0.049 & 0.049 & 0.120 & 0.901 \\
\hline \multirow{2}{*}{ Cash holding } & $\mathrm{U}$ & 0.371 & 0.256 & 7.330 & 0.000 \\
\hline & $\mathrm{M}$ & 0.371 & 0.353 & 1.010 & 0.311 \\
\hline \multirow{2}{*}{$\mathrm{R} \& \mathrm{D}$} & $\mathrm{U}$ & 17.670 & 17.325 & 5.720 & 0.000 \\
\hline & $\mathrm{M}$ & 17.670 & 17.662 & 0.150 & 0.885 \\
\hline \multirow{2}{*}{ Subsidy } & $\mathrm{U}$ & 16.279 & 16.254 & 0.340 & 0.736 \\
\hline & $\mathrm{M}$ & 16.279 & 16.091 & 2.320 & 0.020 \\
\hline \multirow{2}{*}{ Top hold } & $\mathrm{U}$ & 0.349 & 0.375 & -4.400 & 0.000 \\
\hline & $\mathrm{M}$ & 0.349 & 0.338 & 1.830 & 0.068 \\
\hline \multirow{2}{*}{ TMT size } & $\mathrm{U}$ & 7.453 & 7.267 & 1.980 & 0.048 \\
\hline & $\mathrm{M}$ & 7.453 & 7.387 & 0.670 & 0.500 \\
\hline \multirow{2}{*}{ Duality } & $\mathrm{U}$ & 0.361 & 0.115 & 15.450 & 0.000 \\
\hline & $\mathrm{M}$ & 0.361 & 0.362 & -0.040 & 0.967 \\
\hline
\end{tabular}


TABLE 9: Robust check for the effects of CEO media on green invention and green utility.

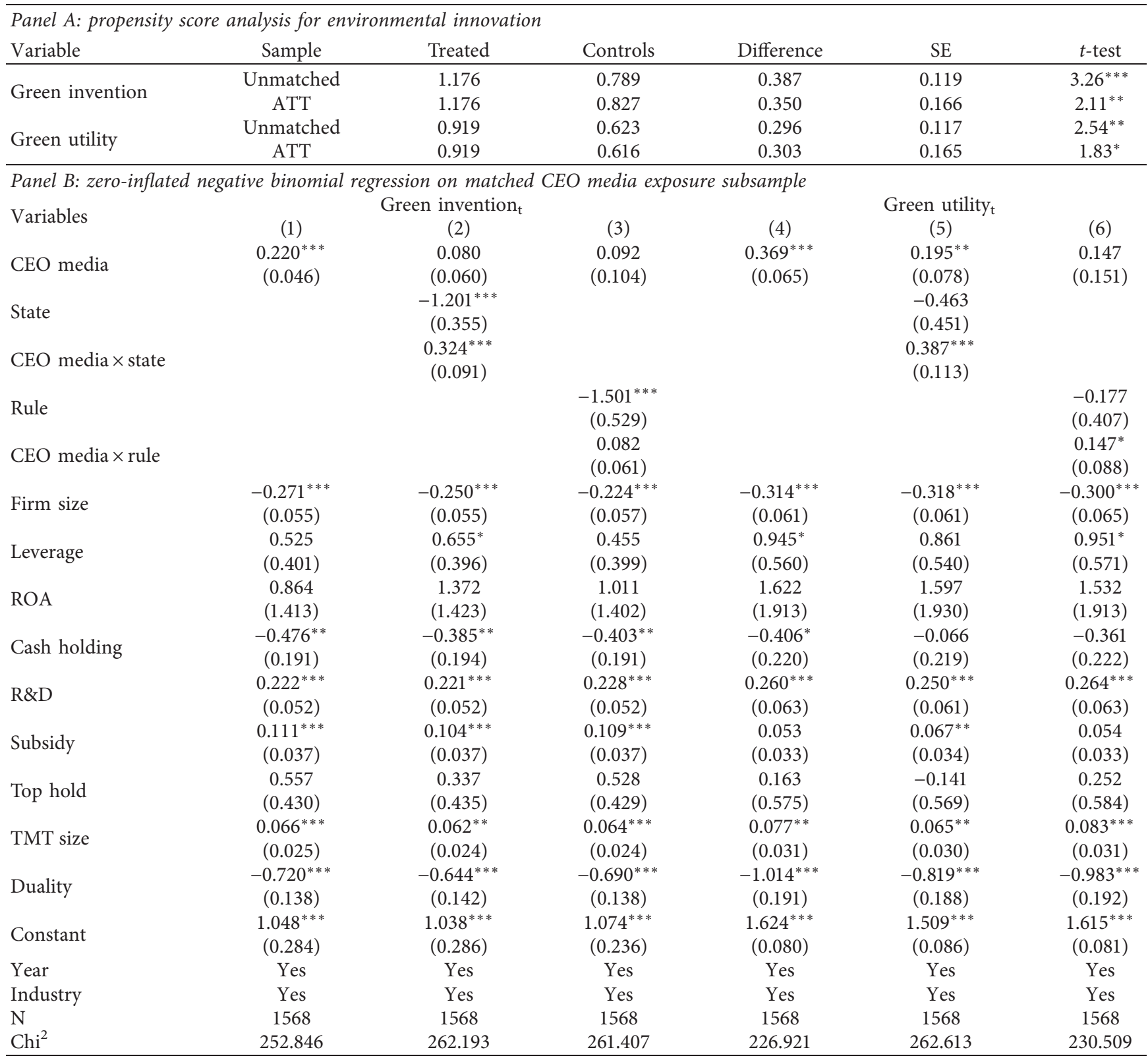

Note that standard errors are in parentheses: ${ }^{*} p<0.1 ;{ }^{* *} p<0.05 ;{ }^{* * *} p<0.01$.

The balance improvements after matching are summarized in Table 8. Panel A of Table 9 shows the propensity score analysis for green innovation; the results show that there is significant and positive relation between high level CEO exposure and green invention $(p<0.05)$, suggesting that firms with high level CEO exposure are able to increase firm innovation ability. Then, we use ZINB model to estimate the relationship between CEO media and green innovation on the corresponding matched sample. Panel B of Table 9 reports the results; the results remain robust reaffirming the CEO media exposure effect.

\section{Concluding Remarks}

In this study, we examine with yearly data the impact of firm CEO's media exposure on the firm green technological innovation. Our sample consists of 2,597 firm-year observations for Chinese companies listed on the Shanghai and Shenzhen Stock Exchanges over the period of 2010-2016. We apply ZINB models to test whether the CEO's media coverage influences the patent application data, which reflects the level of firm green technological innovation. Given the specific market environment in the Chinese economy, 
we consider the effect under different institutional situations. In particular, we investigate the moderating effect of the firm's ownership structure (i.e., state-owned vs. nonstate-owned) and the environmental regulations (i.e., stronger vs. weaker). We also conduct a thorough robustness check for additional validity of our methodology and main findings.

In summary, the empirical test results are generally consistent with our hypotheses. First, CEO media coverage has a positive influence over firm green technological innovation, implying that news reports facilitate the investment in green innovation. Second, the interaction term of CEO media coverage and ownership has a positive impact on firm green innovation for the full sample data, which proves that if the firm is a SOE, the positive influence of CEO media coverage on the firm green innovation will be increased. And the interaction term of CEO media coverage and environmental regulations also has the same influence on firm green innovation, implying that firms with stronger environmental rules will invest more on green innovation. It is apparent that the firm green innovation is exposed to a stronger influence of CEO media coverage when firms are state-owned and operate in stronger environmental regulations.

Our research also provides some important practical implications. Firstly, more attention should be paid to informal systems such as media, which play an important governance role in firm's green technological innovation. As an important aspect of external governance, the external regulatory pressure of media attention has a positive effect on firm's environmental protection innovation behavior. Therefore, we should promote the role of media supervision and reputation mechanism, make it an important external mechanism of corporate environmental governance, promote companies to fulfill actively their social responsibilities, and enhance the level of environmental innovation of enterprises.

Secondly, we ought to strengthen the level of environmental regulation and promote information disclosure and public participation. The effect of CEO media exposure on firm green innovation under the different intensity of environmental regulation not only reflects the quality of regulation and the effect of implementation, but also shows that the strengthening of moderate environmental regulation plays its supervisory part and promotes firm green innovation decision. Media participation in environmental governance under environmental regulation has played a greater role, indicating that public opinion has restrictive and supervisory function. Therefore, the future institutional arrangement of environmental regulation should also consider social regulation and improve the information disclosure system. Join Ministry of Industry and Information Technology and the various regulatory bodies of the Securities Regulatory Commission to give full play to the mechanism of public participation in the supervision of firm green innovation behavior. We should promote enterprises to fulfill their environmental responsibility through stakeholder environmental pressure and form market supervision beyond government supervision.
Thirdly, the support for non-SOE's green innovation should be increased. The result of our study shows that media attention has a more significant impact on firm green innovation of SOE. The essential reason is that the investment cost of environmental protection innovation of stateowned enterprises is guaranteed by the government's "umbrella," while the investment cost of environmental innovation of non-SOEs is mostly borne by themselves. Therefore, we should formulate corresponding environmental regulations and encourage non-SOEs to invest in environment. At the same time, enterprises investing in environmental protection should be given certain tax subsidies or preferential treatment to improve the motivation of non-SOEs investing in environmental protection.

Our study still has some limitations on which further research will be explored. First, there is no distinction between positive or negative media coverage of CEOs. We will further explore the effect of the media exposure distinction on green innovation in the future. Second, there is no specific distinction between media types, such as traditional media and new media and official media and nonofficial media. Future research can further distinguish different types of media and the differences of their attention effects. Third, we did not consider the impact of public perception and mentality (including stock investors) and the intrinsic effect of media ecology (such as media corruption) on green innovation of enterprises from social culture level. Future research may benefit from these works in these directions.

\section{Data Availability}

The data required to reproduce these findings cannot be shared at this time as the data also form part of an ongoing study.

\section{Disclosure}

The co-authors confirm that this work was original research that has not been published previously and was not under consideration for publication elsewhere, in whole or in part.

\section{Conflicts of Interest}

The authors declare that there are no conflicts of interest regarding the submission of this article.

\section{Authors' Contributions}

All the authors have read and approved the final manuscript for publication.

\section{Acknowledgments}

The authors acknowledge the financial support from the National Natural Science Foundation of China (Grant nos. 71702084, 71762020, and 72002029), the Humanity and Social Science Foundation of the Ministry of Education of China (17YJC630112 and 20YJA840022), the Heilongjiang Province Postdoctoral Science Foundation (LBH-Q19086), the Humanity and Social Science Foundation of the Ministry 
of NEPU (WKJD2020001), and the Northeast Petroleum University Innovation Foundation for Postgraduate (YJSCX2017-033NEPU).

\section{References}

[1] P. Qiao, A. Fung, J. Miao, and H.-G. Fung, "Powerful Chief executive Officers and firm performance: integrating agency and stewardship theory," China \& World Economy, vol. 25, no. 6, pp. 100-119, 2017.

[2] Y. Rubashkina, M. Galeotti, and E. Verdolini, "Environmental regulation and competitiveness: empirical evidence on the Porter Hypothesis from European manufacturing sectors," Energy Policy, vol. 83, pp. 288-300, 2015.

[3] Y. Su and X. L. An, "Application of threshold regression analysis to study the impact of regional technological innovation level on sustainable development," Renewable \& Sustainable Energy Reviews, vol. 89, pp. 27-32, 2018.

[4] Y. Bai, S. Song, J. Jiao, and R. Yang, "The impacts of government R\&D subsidies on green innovation: Evidence from Chinese energy-intensive firms," Journal of Cleaner Production, vol. 233, pp. 819-829, 2019.

[5] J. Zhang, W. Zhang, Q. Song et al., "Can energy saving policies drive firm innovation behaviors? - Evidence from China," Technological Forecasting and Social Change, vol. 154, Article ID 119953, 2020.

[6] Y. Liu, J. Zhu, E. Y. Li, Z. Meng, and Y. Song, "Environmental regulation, green technological innovation, and eco-efficiency: the case of Yangtze river economic belt in China," Technological Forecasting and Social Change, vol. 155, 2020.

[7] P.-h. Qiao, H.-G. Fung, and W. Wang, "Chinese firms' crash risk and CEO media exposure," Applied Economics Letters, vol. 25, no. 14, pp. 1034-1037, 2018.

[8] X. Li, P. Qiao, and L. Zhao, "CEO media exposure, political connection and Chinese firms' stock price synchronicity," International Review of Economics \& Finance, vol. 63, pp. 61-75, 2019.

[9] J. Godosdiez, L. Cabezagarcia, R. Fernandezgago, and M. Nietoantolin, "Does CEO media exposure affect corporate social responsibility?" Corporate Social Responsibility and Environmental Management, vol. 27, no. 2, pp. 825-840, 2020.

[10] C. H. Donald and A. M. Phyllis, "Upper echelons: the organization as a reflection of its top managers," Academy of Management Review, vol. 9, no. 2, pp. 193-206, 1984.

[11] L. E. Ginzel, R. M. Kramer, and R. I. Sutton, "Organizational impression management as a reciprocal influence process: the neglected role of the organizational audience," in Organizational Identity, pp. 223-261, Oxford University Press, Oxford, UK, 2004.

[12] Y. Su and Y.-Q. Yu, "Spatial agglomeration of new energy industries on the performance of regional pollution control through spatial econometric analysis," Science of The Total Environment, vol. 704, Article ID 135261, 2020.

[13] D. Li, M. Zheng, C. Cao, X. Chen, S. Ren, and M. Huang, "The impact of legitimacy pressure and corporate profitability on green innovation: evidence from China top 100," Journal of Cleaner Production, vol. 141, pp. 41-49, 2017.

[14] C. E. Carroll and M. Mccombs, "Agenda-setting effects of business news on the public's images and opinions about major corporations," Journalism \& Communication Review, vol. 6, no. 1, pp. 36-46, 2005.

[15] A. Dyck, N. Volchkova, and L. Zingales, "The corporate governance role of the media: evidence from Russia," The Journal of Finance, vol. 63, no. 3, pp. 1093-1135, 2008.
[16] O. Guldiken, C. Tupper, A. Nair, and H. Yu, "The impact of media coverage on ipo stock performance," Journal of Business Research, vol. 72, pp. 24-32, 2017.

[17] Z. Guo, K. C. Chan, and J. Huang, "Can media coverage restrain executive empire building and pursuit of a quiet life? evidence from China," International Review of Economics \& Finance, vol. 56, pp. 547-563, 2018.

[18] M. Bertrand and S. Mullainathan, "Enjoying the quiet life? Corporate governance and managerial preferences," Journal of Political Economy, vol. 111, no. 5, pp. 1043-1075, 2003.

[19] G. D. Saxton and A. E. Anker, "The aggregate effects of decentralized knowledge production: financial bloggers and information asymmetries in the stock market," Journal of Communication, vol. 63, no. 6, pp. 1054-1069, 2013.

[20] P. C. Tetlock and C. Paul, "Does public financial news resolve asymmetric information?" Review of Financial Studies, vol. 23, no. 9, pp. 3520-3557, 2010.

[21] M. K. Bednar, "Watchdog or lapdog? A behavioral view of the media as a corporate governance mechanism," Academy of Management Journal, vol. 55, no. 1, pp. 131-150, 2012.

[22] S. F. Cahan, C. Chen, L. Chen, and N. H. Nguyen, "Corporate social responsibility and media coverage," Journal of Banking \& Finance, vol. 59, pp. 409-422, 2015.

[23] B. D. Nguyen, "Is more news good news? Media coverage of CEOs, firm value, and rent extraction," Quarterly Journal of Finance, vol. 5, no. 4, pp. 1-38, 2015.

[24] S. K. Byun and J.-M. Oh, "Local corporate social responsibility, media coverage, and shareholder value," Journal of Banking \& Finance, vol. 87, pp. 68-86, 2018.

[25] C. Pellegrino and S. Lodhia, "Climate change accounting and the Australian mining industry: exploring the links between corporate disclosure and the generation of legitimacy," Journal of Cleaner Production, vol. 36, pp. 68-82, 2012.

[26] Gusenburg, L. 2014. CEOs: You Can't Afford to Ignore Social Media Anymore. https://blog.hubspot.com/marketing/ceosyou-cant-afford-to-ignore-social-media-anymore.

[27] M. C. Suchman, "Managing legitimacy: strategic and institutional approaches," The Academy of Management Review, vol. 20, no. 3, pp. 571-610, 1995.

[28] Z. Liu, X. Li, X. Peng, and S. Lee, "Green or nongreen innovation? Different strategic preferences among subsidized enterprises with different ownership types," Journal of Cleaner Production, vol. 245, Article ID 118786, 2019.

[29] T. G. Pollock and V. P. Rindova, "Media legitimation effects in the market for initial public offerings," Academy of Management Journal, vol. 46, no. 5, pp. 631-642, 2003.

[30] G. Jin, K. Shen, and J. Li, "Interjurisdiction political competition and green total factor productivity in China: an inverted-U relationship," China Economic Review, vol. 61, Article ID 101224, 2020.

[31] H. Jin, Y. Qian, and B. R. Weingast, "Regional decentralization and fiscal incentives: federalism, Chinese style," Journal of Public Economics, vol. 89, no. 9-10, pp. 1719-1742, 2005.

[32] J. Guan and R. C. M. Yam, "Effects of government financial incentives on firms' innovation performance in China: evidences from Beijing in the 1990s," Research Policy, vol. 44, no. 1, pp. 273-282, 2015.

[33] A. M. Leiter, A. Parolini, and H. Winner, "Environmental regulation and investment: evidence from European industry data," Ecological Economics, vol. 70, no. 4, pp. 759-770, 2011.

[34] A. Shleifer and R. W. Vishny, "Politicians and firms," The Quarterly Journal of Economics, vol. 109, no. 4, pp. 995-1025, 1994. 
[35] P. Bansal and I. Clelland, "Talking trash: legitimacy, impression management, and unsystematic risk in the context of the natural environment," Academy of Management Journal, vol. 47, no. 1, pp. 93-103, 2004.

[36] E. Kesidou and P. Demirel, "On the drivers of eco-innovations: empirical evidence from the UK," Research Policy, vol. 41, no. 5, pp. 862-870, 2012.

[37] M. E. Porter and C. V. D. Linde, "Toward a new conception of the environment-competitiveness relationship," Journal of Economic Perspectives, vol. 9, no. 4, pp. 97-118, 1995.

[38] P. Lanoie, J. Laurent-Lucchetti, N. Johnstone, and S. Ambec, "Environmental policy, innovation and performance: new insights on the porter hypothesis," Journal of Economics \& Management Strategy, vol. 20, no. 3, pp. 803-842, 2011.

[39] M. Saygili and Meryem, "Pollution abatement costs and productivity: does the type of cost matter?" Letters in Spatial and Resource Sciences, vol. 9, no. 1, pp. 1-7, 2016.

[40] K. H. Lee and B. Min, "Green R\&D for eco-innovation and its impact on carbon emissions and firm performance," Journal of Cleaner Production, vol. 108, pp. 534-542, 2015.

[41] P. Berrone, A. Fosfuri, L. Gelabert, and L. R. Gomez-Mejia, "Necessity as the mother of "green" inventions: Institutional pressures and environmental innovations," Strategic Management Journal, vol. 34, no. 8, pp. 891-909, 2013.

[42] J. Zhang, X. Li, H. G. Fung, and P. Qiao, "Do political connections promote innovation in environmentally polluting enterprises?" China \& World Economy, vol. 27, no. 3, pp. 76-101, 2019.

[43] D. Li, M. Zheng, C. Cao, X. Chen, S. Ren, and M. Huang, "The impact of legitimacy pressure and corporate profitability on green innovation: Evidence from China top 100," Journal of Cleaner Production, vol. 141, pp. 41-49, 2017.

[44] B. S. Javorcik and S. J. Wei, "Pollution havens and foreign direct investment: dirty secret or popular myth?" The BE Journal of Economic Analysis \& Policy, vol. 3, no. 2, pp. 76101, 2003.

[45] W. H. Greene, Econometric Analysis, Prentice-Hall, Upper Saddle River, NJ, USA, 5th edition, 2003.

[46] H.-G. Fung, P. Qiao, J. Yau, and Y. Zeng, "Leader narcissism and outward foreign direct investment: evidence from Chinese firms," International Business Review, vol. 29, no. 1, Article ID 101632, 2020.

[47] R. H. Dehejia and S. Wahba, "Propensity score-matching methods for nonexperimental causal studies," Review of Economics and statistics, vol. 84, no. 1, pp. 151-161, 2002. 